\title{
Genetic Differences among C57BL/6 Substrains
}

\author{
Kazuyuki MEKADA, Kuniya ABE, Ayumi MURAKAMI, Satoe NAKAMURA, \\ Hatsumi NAKATA, Kazuo MORIWAKI, Yuichi OBATA, and Atsushi YOSHIKI
}

RIKEN BioResource Center, 3-1-1 Koyadai, Tsukuba, Ibaraki 305-0074, Japan

\begin{abstract}
The C57BL/6 mouse is the most well-known inbred mouse strain, and has been widely used as a genetic background for congenic and mutant mice. A number of C57BL/6 substrains have been derived from the C57BL/6 founder line and are reported to differ in several phenotypes. There are several major sources of C57BL/6 substrains for the biomedical research community. The importance of their genetic and phenotypic differences among substrains, however, has not yet been well recognized by biomedical researchers. Here, we report the result of screening of the functional deletion of the nicotinamide nucleotide transhydrogenase (Nnt) gene and 1,446 SNPs genotyping among seven C57BL/6 substrains from different sources, such as C57BL/6J, C57BL/6JJcl, C57BL/6JJmsSlc, C57BL/6NJcl, C57BL/6NCrICrlj, C57BL/6NTac, and C57BL/6CrSlc. The deletion of exon 7-11 in the Nnt gene that was previously reported in C57BL/6J was also observed in other C57BL/6J substrains, indicating that this functional deletion probably occurred at an early stage in the establishment of C57BL/6J substrains. The genotyping of SNP loci clearly demonstrate genetic differences between C57BL/6J and C57BL/6N substrains at 11 loci. Besides, we found another SNP differing between C57BL/6J and other C57BL/6J substrains available from commercial breeders. No genetic difference was detected among C57BL/6N substrains. The C57BL/6CrSlc mouse, originally derived from the National Cancer Institute of the NIH was found to be the same as the C57BL/6N substrains by the SNP pattern. These data will be useful for accurate genetic monitoring of genetically engineered mice with the C57BL/6 background.
\end{abstract}

Key words: C57BL/6, genetic background, inbred strain, SNP, substrain

\section{Introduction}

Inbred mouse strains are generated by sister-brother mating for 20 or more consecutive generations [4]. The history of inbred strains is closely linked to the development of research in cancer and immunology. The most famous early inbred lines include the $\mathrm{C} 57 \mathrm{BL} / 6$, $\mathrm{C} 57 \mathrm{BL} / 10, \mathrm{C} 3 \mathrm{H}, \mathrm{CBA}$, and BALB/c strains which were originally developed to demonstrate the genetic basis for various forms of cancer. These inbred lines have played a crucial role in all areas of biomedical research by allowing independent researchers all over the globe to perform reproducible experiments on the same genetic material [26].

Substrains are defined as branches of an inbred strain that are either known or suspected to be genetically different from the original inbred strain due to any of the following conditions: branches of a strain which separate

(Received 27 August 2008 / Accepted 18 December 2008)

Address corresponding: A. Yoshiki, RIKEN BioResource Center, 3-1-1 Koyadai, Tsukuba, Ibaraki 305-0074, Japan 
after 20, but before 40 generations of inbreeding; branches separated by more than 20 generations from a common ancestor; and genetic differences between branches [6].

The C57BL/6 mouse is the most well-known inbred strain derived from the C57BL strain that was established by C.C. Little in the 1920 s, and has been widely used as a general purpose strain and a genetic background for spontaneous and induced mutant mice. C57BL/6 separated from the C57BL parent strain along with C57BL/10 in the mid-1930s, and at least nine C57BL/6 substrains were also established in the 1970s [8,9]. Above all, C57BL/6J of The Jackson Laboratory and C57BL/6N of the National Institutes of Health (NIH) are core substrains of $\mathrm{C} 57 \mathrm{BL} / 6$, that were developed from the ancestral C57BL/6 line during the 1940s and 1950s [1, $2]$.

It has been reported that there are phenotypic differences among the C57BL/6 substrains, especially related to several behaviors $[3,13,19,22,25,27,28]$ and tolerance for glucose $[11,15,29]$, alcohol $[12,18]$, and drugs $[5,23]$. The deletion of functional gene was reported in C57BL/6J [11, 15], such as the deletion of exons 7-11 in the nicotinamide nucleotide transhydrogenase (Nnt) gene, while the $N n t$ gene remains intact in C57BL/6JEi, C57BL/6NCrl and C57BL/6ByJ [29]. Since the Nnt gene is important for glucose homeostasis and controls insulin secretion, the C57BL/6J mouse lacks these important characters. Therefore, biomedical researchers must recognize these differences in the C57BL/6 substrains and choose an appropriate substrain for the specific purpose of their studies.

Single nucleotide polymorphisms (SNPs) are the most abundant class of genetic markers in the genome. Comparison of the genomic sequence of the C57BL/6J strain [20] with those of other strains revealed that SNPs are extremely abundant $[14,21,30-33]$. The use of SNP markers can also help to distinguish genetically close strains such as substrains with potential genetic differences. Several SNPs among C57BL/6 substrains were made public in the SNP database of MGI-Mouse Strains, SNPs \& Polymorphisms (http://www/informatics.jax. org/strains_SNPs.shtml), the MPD-Mouse SNPs (http:// phenome.jax.org/pub-cgi/phenome/mpdcgi?rtn=snps/ door), and the JAX Mice database (http://jaxmice.jax. org/strain/000664.html). However, only a limited number of SNPs from direct comparison of C57BL/6J and $\mathrm{N}$ substrains are included in these databases.

Here, we demonstrate novel SNPs between C57BL/6J and $\mathrm{C} 57 \mathrm{BL} / 6 \mathrm{~N}$ substrains, and the presence of a functional deletion of the $N n t$ gene in $\mathrm{C} 57 \mathrm{BL} / 6 \mathrm{~J}$ substrains. These data will be useful to distinguish C57BL/6 substrains, especially $\mathrm{J}$ or $\mathrm{N}$, for the genetic background of mouse strains.

\section{Materials and Methods}

\section{Mice}

C57BL/6J was purchased from The Jackson Laboratory (Bar Harbor, Maine, USA). C57BL/6NCrlCrlj and $\mathrm{C} 3 \mathrm{H} / \mathrm{HeNCrlCrlj}$ were purchased from Charles River Laboratories Japan, Inc. (Yokohama, Japan). C57BL/6JJcl, C57BL/6NJcl, BALB/cAJcl, DBA/2JJcl, and NOD/ShiJic were obtained from CLEA Japan, Inc. (Tokyo, Japan). C57BL/6JJmsSlc, C57BL/6CrSlc, and C57BL/10SnJSlc were obtained from Japan SLC, Inc. (Hamamatsu, Japan). C57BL/6NTa was obtained from Taconic Farms, Inc. (Hudson, New York, USA). C57BL/10SnJSlc, BALB/cAJcl, C3H/HeNCrlCrlj, $\mathrm{DBA} / 2 \mathrm{JJcl}$, and NOD/ShiJic were subjected to the analysis of the deletion of the Nnt gene locus as controls. All animal experiments were conducted in accordance with the Regulations for the Animal Experiments of RIKEN (October 1, 2003 Rule No. 129, last amendment on March 31, 2008 Rule No. 29). Our experimental protocols, including animals (Exp08-002) were approved by the Animal Experiments Committee of the RIKEN Tsukuba Institute.

\section{SNP genotyping}

Genomic DNA was extracted from the tail tips or kidneys of mice by using an automatic nucleic acid isolation system (NA-2000, KURABO Industries Ltd., Osaka, Japan). The concentration of genomic DNA was calibrated to suit the subsequent process in accordance with the manufacturer's instructions. Genotyping of 1,449 SNP loci covering the genome was carried out by using the Golden Gate assay (Illumina Inc., San Diego, California, USA) [7] of Illumina's Mouse MD Linkage Panel. Based on information of over 13,000 SNPs from 
480 strains (Welcome Trust Centre for Human Genetics, http://www.well.ox.ac.uk/mouse/INBREDS), the SNP loci of Illumina's Mouse MD Linkage Panel were standardized to maximize the genetic information across the common inbred strains, including 129S1/SvImJ, AKR/J, $\mathrm{BALB} / \mathrm{cJ}, \mathrm{C} 3 \mathrm{H} / \mathrm{HeJ}, \mathrm{C} 57 \mathrm{BL} / 6 \mathrm{~J}, \mathrm{CBA} / \mathrm{J}, \mathrm{DBA} / 2 \mathrm{~J}, \mathrm{FVB} /$ $\mathrm{NJ}, \mathrm{NOD} / \mathrm{LtJ}$, and SJL/J. Their loci were designed to include approximately three SNPs per five megabases.

\section{Genomic PCR}

To determine if the $\mathrm{C} 57 \mathrm{BL} / 6 \mathrm{~J}$ specific deletion of the Nnt gene locus existed in the C57BL/6 substrains, exonspecific primers for the $\mathrm{Nnt}$ gene were designed according to a previous report [15]. All oligonucleotides used in this study were synthesized by Invitrogen Japan (Tokyo, Japan). PCRs were performed in a total volume of $12 \mu 1$. The reaction mixture contained $6.0 \mu 1$ of $2 \times$ QIAGEN Multiplex PCR Master Mix (QIAGEN GmbH, Hilden, Germany), $1.2 \mu 1$ of $2.0 \mu \mathrm{M}$ primer mix of forward and reverse primers, $3.3 \mu \mathrm{l}$ of RNase-free water, and $1.5 \mu 1$ of template DNA (less than $1 \mu \mathrm{g}$ DNA/50 $\mu \mathrm{l}$ ). Thermal cycling conditions for the PCR were as follows: $15 \mathrm{~min}$ at $95^{\circ} \mathrm{C}$, followed by 32 cycles of $94^{\circ} \mathrm{C}$ for 30 sec, $60^{\circ} \mathrm{C}$ for $90 \mathrm{sec}$, and $72^{\circ} \mathrm{C}$ for $90 \mathrm{sec}$, with a final extension at $72^{\circ} \mathrm{C}$ for $10 \mathrm{~min}$. All PCR amplifications were performed using a T1 Biometra thermal cycler (Whatman Biometra GmbH, Niedersachsen, Germany). An aliquot of $5 \mu 1$ from each of the completed PCR, was mixed with $1 \mu 1$ of $6 \times$ loading buffer $(0.5 \%$ bromophenol blue in $50 \%$ glycerol) and subjected to electrophoresis on 4\% NuSieve 3:1 Agarose gel (Lonza Rockland, Inc., Rockland, Maine, USA). Electrophoresis was performed in $1 \times$ TAE ( $40 \mathrm{mM}$ Tris- $\mathrm{HCl}, 20 \mathrm{mM}$ Sodium Acetate, $2.0 \mathrm{mM}$ EDTA) buffer for $30-40 \mathrm{~min}$ at $100 \mathrm{~V}$ using a submarine style electrophoresis unit (Mupid-alpha, ADVANCE Co., Ltd., Tokyo, Japan). The gel was stained with $1.0 \mu \mathrm{g} / \mathrm{ml}$ ethidium bromide solution for $10 \mathrm{~min}$ and photographed by an ultraviolet trans-illuminator and a digital photographic device (FAS-III, TOYOBO Co., Ltd., Osaka, Japan).

\section{Allele frequency data}

Data for the allele frequency for the C57BL/6J versus C57BL/6N alleles of each SNP locus were obtained from Illumina's product catalog and the dbSNP database
(NCBI Entrez SNP, http://www.ncbi.nlm.nih.gov/SNP) for two different sets of inbred strains, TWGNF: TWGNF-Mouse-2 and ABI: CRAMUS_MOUSE [24]. These two populations include the following inbred strains: A/J, AKR/J, BALB/cByJ, BTBR, BUB/BnJ, C3H/HeJ, C57BL/10J, C57BL/6J, C57BLKS/J, C57BR/ cdJ, C57L/J, C58/J, CAST/Ei, CBA/J, CE/J, CZECHII/ Ei, DBA/1J, DBA/2J, DDK/Pas, FVB/NJ, I/LnJ, JF1/ Ms, KK/HIJ, LG/J, LP/J, MA/MyJ, MAI/Pas, MOLF/ Ei, MSM/Ms, NOD/LtJ, NON/LtJ, NZB/BINJ, NZW/ LacJ, PERA/Ei, PL/J, PWD/Ph, RIIIS/J, SEA/GnJ, SEG/ Pas, SJL/J, SM/J, SPRET/Ei, ST/bJ, SWR/J, WSB/Ei, ZALENDE/Ei, 129S1/SvImJ, and 129X1/SvJ. We used only the values of the allele frequency which were consistent in repetitive assays or in the two strain sets.

\section{Results}

\section{SNP genotyping}

SNP genotyping was carried out on seven C57BL/6 substrains by using Illumina's Mouse MD Linkage Panels for 1,449 SNP loci. One thousand four hundred twentyseven (98.5\%) targeted SNP loci were successfully genotyped. The remaining assays produced statistically unreliable values. Eleven novel SNPs (rs13478783, rs13479522,rs13480122, rs13480619, CEL-10_58149652, rs13480759, rs13481014, rs13481734, CEL14_116404928, rs4165065, and rs13483055) were detected between $\mathrm{C} 57 \mathrm{BL} / 6 \mathrm{~J}$ and $\mathrm{C} 57 \mathrm{BL} / 6 \mathrm{~N}$ substrains as shown in Table 1. Besides, we found another SNP at the rs 13477019 locus on chromosome 3 between the C57BL/6J substrain and other C57BL/6 substrains. Therefore, we detected 12 SNPs between the C57BL/6J substrain and C57BL/6N substrains, indicating that $0.8 \%$ of SNP loci were genetically distinct between the $\mathrm{C} 57 \mathrm{BL} / 6 \mathrm{~J}$ substrain and C57BL/6N substrains.

\section{SNP type and allele frequency}

As summarized in Table 2, the 12 genetically distinct SNPs were in the genome SNP or the intronic SNP, located in non-coding regions of the genome, according to the Ensembl Mouse Genome Server (www.ensembl. org/Mus_musculus/Info/Index) [16]. Moreover, the allele frequency data for the C57BL/6J versus the C57BL/6N alleles from the database indicated that the 
Table 1. SNPs among C57BL/6 substrains

\begin{tabular}{|c|c|c|c|c|c|c|}
\hline $\begin{array}{l}\text { Chromosome } \\
\text { locus }\end{array}$ & $\begin{array}{c}3 \\
\text { rs } 13477019\end{array}$ & $\begin{array}{c}6 \\
\text { rs } 13478783\end{array}$ & $\begin{array}{c}7 \\
\text { rs } 13479522\end{array}$ & $\begin{array}{c}9 \\
\text { rs } 13480122\end{array}$ & $\begin{array}{c}10 \\
\text { rs } 13480619\end{array}$ & $\begin{array}{c}10 \\
\text { CEL-10_58149652 }\end{array}$ \\
\hline C57BL/6J & $\mathrm{T} / \mathrm{T}$ & $\mathrm{A} / \mathrm{A}$ & $\mathrm{A} / \mathrm{A}$ & $\mathrm{T} / \mathrm{T}$ & $\mathrm{T} / \mathrm{T}$ & $\mathrm{G} / \mathrm{G}$ \\
\hline C57BL/6JJcl & $\mathrm{A} / \mathrm{A}$ & $\mathrm{A} / \mathrm{A}$ & $\mathrm{A} / \mathrm{A}$ & $\mathrm{T} / \mathrm{T}$ & $\mathrm{T} / \mathrm{T}$ & $\mathrm{G} / \mathrm{G}$ \\
\hline C57BL/6JJmsSlc & $\mathrm{A} / \mathrm{A}$ & $\mathrm{A} / \mathrm{A}$ & $\mathrm{A} / \mathrm{A}$ & $\mathrm{T} / \mathrm{T}$ & $\mathrm{T} / \mathrm{T}$ & $\mathrm{G} / \mathrm{G}$ \\
\hline C57BL/6NJcl & $\mathrm{A} / \mathrm{A}$ & $\mathrm{G} / \mathrm{G}$ & $\mathrm{G} / \mathrm{G}$ & $\mathrm{C} / \mathrm{C}$ & $\mathrm{C} / \mathrm{C}$ & $\mathrm{A} / \mathrm{A}$ \\
\hline C57BL/6NCrlCrlj & $\mathrm{A} / \mathrm{A}$ & $\mathrm{G} / \mathrm{G}$ & $\mathrm{G} / \mathrm{G}$ & $\mathrm{C} / \mathrm{C}$ & $\mathrm{C} / \mathrm{C}$ & $\mathrm{A} / \mathrm{A}$ \\
\hline C57BL/6NTac & $\mathrm{A} / \mathrm{A}$ & $\mathrm{G} / \mathrm{G}$ & $\mathrm{G} / \mathrm{G}$ & $\mathrm{C} / \mathrm{C}$ & $\mathrm{C} / \mathrm{C}$ & $\mathrm{A} / \mathrm{A}$ \\
\hline $\mathrm{C} 57 \mathrm{BL} / 6 \mathrm{CrSlc}$ & $\mathrm{A} / \mathrm{A}$ & $\mathrm{G} / \mathrm{G}$ & $\mathrm{G} / \mathrm{G}$ & $\mathrm{C} / \mathrm{C}$ & $\mathrm{C} / \mathrm{C}$ & $\mathrm{A} / \mathrm{A}$ \\
\hline Chromosome & 10 & 11 & 13 & 14 & 16 & 17 \\
\hline locus & rs 13480759 & rs 13481014 & rs 13481734 & CEL-14_116404928 & rs4165065 & rs 13483055 \\
\hline C57BL/6J & $\mathrm{C} / \mathrm{C}$ & $\mathrm{T} / \mathrm{T}$ & $\mathrm{A} / \mathrm{A}$ & $\mathrm{G} / \mathrm{G}$ & $\mathrm{T} / \mathrm{T}$ & $\mathrm{T} / \mathrm{T}$ \\
\hline C57BL/6JJcl & $\mathrm{C} / \mathrm{C}$ & $\mathrm{T} / \mathrm{T}$ & $\mathrm{A} / \mathrm{A}$ & $\mathrm{G} / \mathrm{G}$ & $\mathrm{T} / \mathrm{T}$ & $\mathrm{T} / \mathrm{T}$ \\
\hline C57BL/6JJmsSlc & $\mathrm{C} / \mathrm{C}$ & $\mathrm{T} / \mathrm{T}$ & $\mathrm{A} / \mathrm{A}$ & $\mathrm{G} / \mathrm{G}$ & $\mathrm{T} / \mathrm{T}$ & $\mathrm{T} / \mathrm{T}$ \\
\hline C57BL/6NJcl & $\mathrm{T} / \mathrm{T}$ & $\mathrm{C} / \mathrm{C}$ & $\mathrm{G} / \mathrm{G}$ & $\mathrm{A} / \mathrm{A}$ & $\mathrm{C} / \mathrm{C}$ & $\mathrm{C} / \mathrm{C}$ \\
\hline C57BL/6NCrlCrlj & $\mathrm{T} / \mathrm{T}$ & $\mathrm{C} / \mathrm{C}$ & $\mathrm{G} / \mathrm{G}$ & $\mathrm{A} / \mathrm{A}$ & $\mathrm{C} / \mathrm{C}$ & $\mathrm{C} / \mathrm{C}$ \\
\hline C57BL/6NTac & $\mathrm{T} / \mathrm{T}$ & $\mathrm{C} / \mathrm{C}$ & $\mathrm{G} / \mathrm{G}$ & $\mathrm{A} / \mathrm{A}$ & $\mathrm{C} / \mathrm{C}$ & $\mathrm{C} / \mathrm{C}$ \\
\hline C57BL/6CrSlc & $\mathrm{T} / \mathrm{T}$ & $\mathrm{C} / \mathrm{C}$ & $\mathrm{G} / \mathrm{G}$ & $\mathrm{A} / \mathrm{A}$ & $\mathrm{C} / \mathrm{C}$ & $\mathrm{C} / \mathrm{C}$ \\
\hline
\end{tabular}

Table 2. Status of twelve SNP loci and allele frquencies of C57BL/6J and C57BL/6N alleles

\begin{tabular}{|c|c|c|c|c|c|c|c|}
\hline \multirow[b]{2}{*}{ Reference SNP ID } & \multirow[b]{2}{*}{ Chromosome } & \multirow[b]{2}{*}{$\begin{array}{c}\text { Position (bp) } \\
\text { (NCBI build 37) }\end{array}$} & \multirow[b]{2}{*}{ SNP type } & \multirow[b]{2}{*}{ Gene linked } & \multicolumn{3}{|c|}{ Allele frequencies } \\
\hline & & & & & $\begin{array}{c}\mathrm{C} 57 \mathrm{BL} / 6 \mathrm{~J} \\
\text { allele }\end{array}$ & $\begin{array}{l}\text { Number } \\
\text { of strains }\end{array}$ & $\begin{array}{c}\text { C57BL/6N } \\
\text { allele }\end{array}$ \\
\hline rs13477019 & 3 & $23,723,842$ & intronic & Naaladl2 & $\mathrm{T} / \mathrm{T}$ & 1 vs 23 & $\mathrm{~A} / \mathrm{A}$ \\
\hline rs13478783 & 6 & $60,641,673$ & genomic & - & $\mathrm{A} / \mathrm{A}$ & 4 vs 27 & $\mathrm{G} / \mathrm{G}$ \\
\hline rs13479522 & 7 & $136,179,208$ & genomic & - & $\mathrm{A} / \mathrm{A}$ & 1 vs 42 & $\mathrm{G} / \mathrm{G}$ \\
\hline rs13480122 & 9 & $309,964,211$ & intronic & Aplp2 & $\mathrm{T} / \mathrm{T}$ & 1 vs 27 & $\mathrm{C} / \mathrm{C}$ \\
\hline rs 13480619 & 10 & $57,472,268$ & genomic & - & $\mathrm{T} / \mathrm{T}$ & 1 vs 43 & $\mathrm{C} / \mathrm{C}$ \\
\hline CEL-10_58149652 & 10 & $57,865,252$ & intronic & Lims 1 & $\mathrm{G} / \mathrm{G}$ & 1 vs 9 & $\mathrm{~A} / \mathrm{A}$ \\
\hline rs13480759 & 10 & $108,815,683$ & genomic & - & $\mathrm{C} / \mathrm{C}$ & 1 vs 47 & $\mathrm{~T} / \mathrm{T}$ \\
\hline rs13481014 & 11 & $47,930,884$ & genomic & - & $\mathrm{T} / \mathrm{T}$ & 1 vs 45 & $\mathrm{C} / \mathrm{C}$ \\
\hline rs13481734 & 13 & $27,129,019$ & genomic & - & $\mathrm{A} / \mathrm{A}$ & 1 vs 34 & $\mathrm{G} / \mathrm{G}$ \\
\hline CEL-14_116404928 & 14 & $124,509,120$ & intronic & $F g f 14$ & $\mathrm{G} / \mathrm{G}$ & 1 vs 9 & $\mathrm{~A} / \mathrm{A}$ \\
\hline rs4165065 & 16 & $17,412,172$ & intronic & Snap29 & $\mathrm{T} / \mathrm{T}$ & 1 vs 28 & $\mathrm{C} / \mathrm{C}$ \\
\hline rs13483055 & 17 & $60,459,368$ & genomic & - & $\mathrm{T} / \mathrm{T}$ & 2 vs 44 & $\mathrm{C} / \mathrm{C}$ \\
\hline
\end{tabular}

genomic = genome SNP, intronic = intronic SNP, located in non-coding regions of the genome. Information about the chromosomal position, SNP type, and linked gene was obtained from the Ensembl Mouse Genome Server (www.ensembl.org/ Mus_musculus/Info/Index). Data for the allele frequencies of the C57BL/6J versus C57BL/6N alleles at each SNP locus were obtained from the dbSNP database (http://www.ncbi.nlm.nih.gov/SNP) and Illumina's product catalog.

C57BL/6J alleles were J-specific and $\mathrm{N}$ alleles were common among inbred strains. The genotypes of the 1,427 SNP loci were the same among the C57BL/6N substrains and C57BL/6CrSlc.

\section{Genomic PCR for Nnt gene}

Deletion of exons 7-11 in the Nnt gene was surveyed among the C57BL/6 substrains and other common inbred strains (Fig. 1). The deletion of exon 7-11 in the Nnt gene was only detected in C57BL/6J substrains and not in any of the other strains examined.

\section{Discussion}

This study clearly demonstrated genetic differences between the C57BL/6J substrain and C57BL/6N sub- 


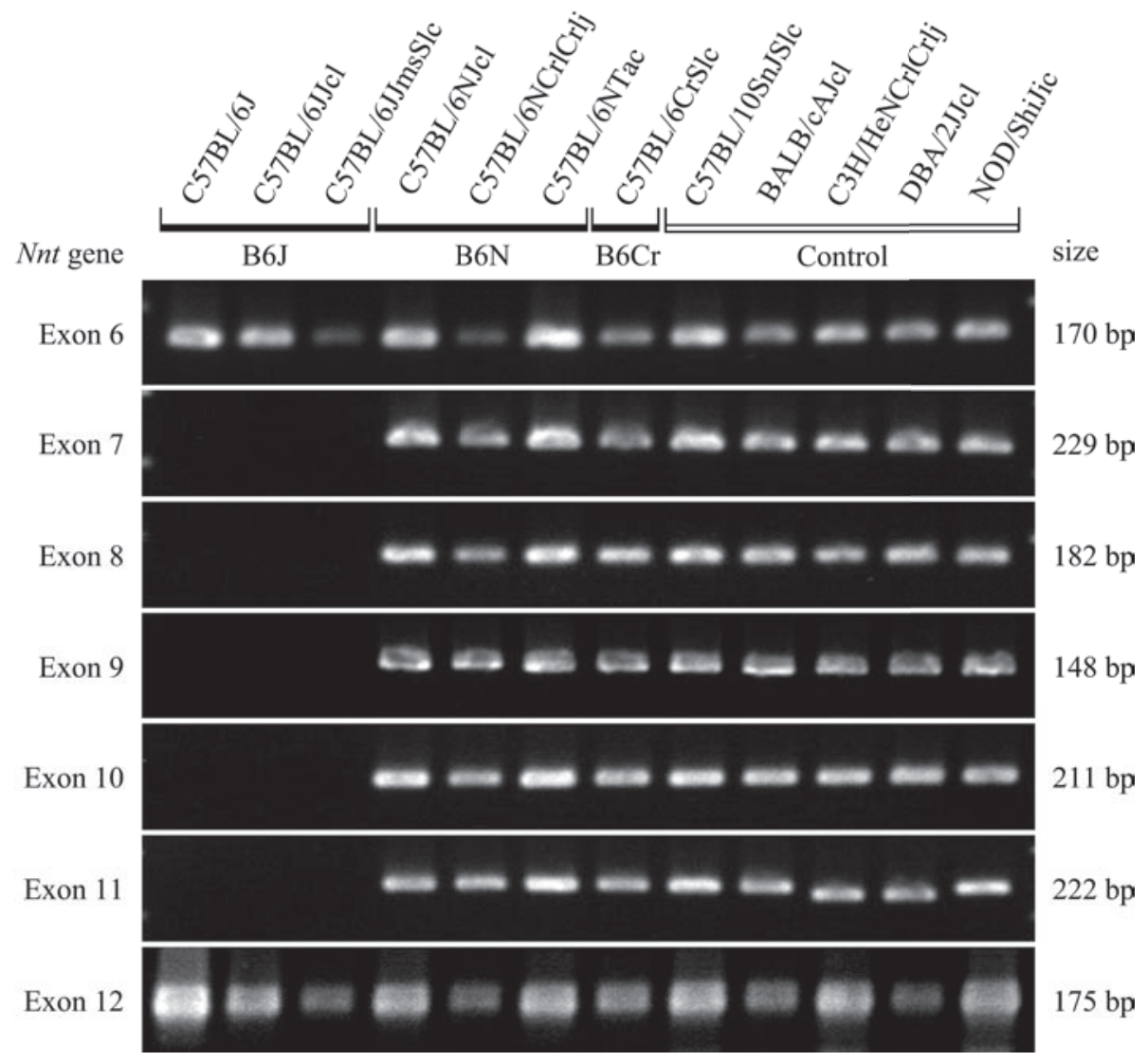

Fig. 1. Absence of exons $7-11$ of the Nnt gene in C57BL/6J substrains. Genomic PCR specific for exons 6-12 of the Nnt gene showed the absence of PCR products from exons 7-11 in $\mathrm{C} 57 \mathrm{BL} / 6 \mathrm{~J}, \mathrm{C} 57 \mathrm{BL} / 6 \mathrm{JJcl}$, and C57BL/6JJmsSlc, suggesting a deletion encompassing exons 7 to 11 in C57BL/6J substrains, exclusively. B6J: C57BL/6J substrains, B6N: C57BL/6N substrains, B6Cr: C57BL/6CrSlc substrain. PCR product size was from Huang et al. [15].

strains at eleven SNP loci and a deletion of exons in the Nnt gene. These SNPs and a deletion of exons in the $N n t$ gene were found exclusively in the C57BL/6J substrains, not in the other $\mathrm{C} 57 \mathrm{BL} / 6 \mathrm{~N}$ substrains and C57BL/6CrSlc. It is also interesting to note that one of the twelve SNPs (SNP ID: rs13477019) detected between the $\mathrm{C} 57 \mathrm{BL} / 6 \mathrm{~J}$ substrain and C57BL/6N substrains was an unique allele only found in the $\mathrm{C} 57 \mathrm{BL} / 6 \mathrm{~J}$ substrain (Table 1). The genotypes of the twelve SNP loci were confirmed by genomic sequencing in different individuals, and the results will be referred elsewhere.

The genealogy of the C57BL/6 substrains used in this study is summarized in Fig. 2. C57BL/6 was separated from the C57BL parent strain and sent to The Jackson Laboratory by Hall at $\mathrm{F}_{24}$ in 1948 , and then sent to NIH at $\mathrm{F}_{32}$ in 1951 , according to the Charles River Laboratories product catalog. It is most likely that the genetic changes occurred and were fixed in the C57BL/6J colony at The Jackson Laboratory after C57BL/6N was separated from the ancestral C57BL/6 founder. These results are also supported by the existence of other C57BL/6J-specific alleles at different SNP loci [21].

According to the descriptions in the product catalogs of breeders, C57BL/6J mice were introduced from The Jackson Laboratory to Japan in the 1980s, to CLEA Japan at $\mathrm{F}_{166}$ in 1989 , and to Japan SLC in 1987 by way of the Institute of Medical Science, The University of Tokyo, and have since been distributed commercially as C57BL/6JJcl and C57BL/6JJmsSlc, respectively. The functional deletion of the Nnt gene probably occurred at 


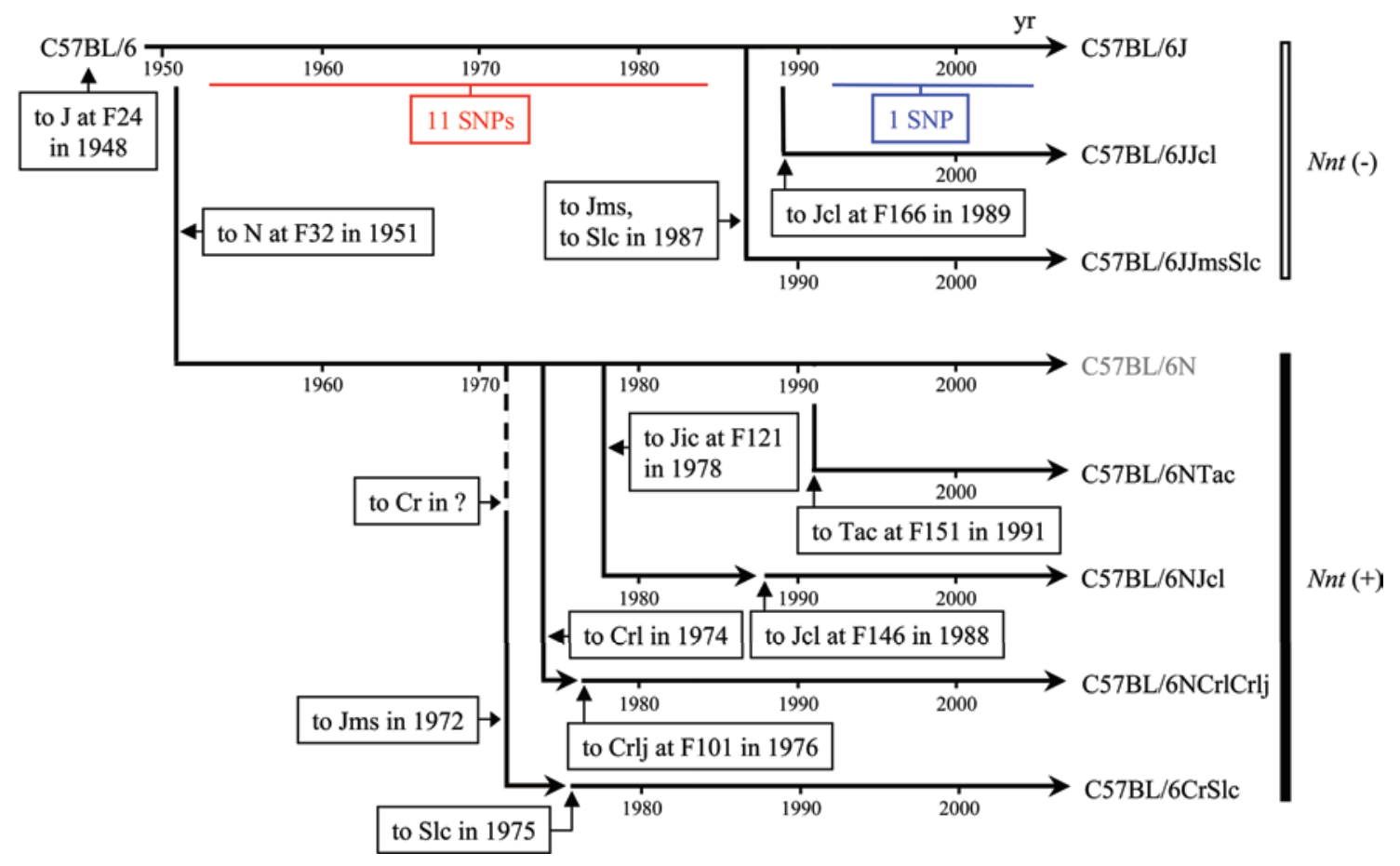

Fig. 2. Genealogy of C57BL/6 substrains, their SNPs and a deletion of the Nnt gene. Cr: National Cancer Institute of the National Institute of Health; Crl: Charles River Laboratories; Crlj: Charles River Laboratories Japan; J: The Jackson Laboratory; Jcl: CLEA Japan; Jic: Central Institute for Experimental Animals; Jms: Institute of Medical Science, The University of Tokyo; N: NIH; Slc: Japan SLC; Tac: Taconic Farms. ?: The year of introduction of C57BL/6N to the NCI from the NIH was unknown. There were eleven SNPs between C57BL/6J and C57BL/6N substrains in a comparison of the 1,427 SNPs. One more SNP was detected between C57BL/6J and other C57BL/6J substrains.

an early stage in the C57BL/6J substrain before they were introduced to Japan. The most probable explanation is that a mutation at the rs 13477019 locus occurred independently in the C57BL/6J colony of The Jackson Laboratory after the C57BL/6J mice were introduced to Japan.

Charles River Laboratories obtained C57BL/6N mice from the NIH in 1974. They were introduced to Charles River Laboratories Japan at $\mathrm{F}_{101}$ in 1976, and since then Charles River Laboratories Japan has been distributing them as $\mathrm{C} 57 \mathrm{BL} / 6 \mathrm{NCrlCrlj}$ (Fig. 2). C57BL/6NJcl was originated from $\mathrm{C} 57 \mathrm{BL} / 6 \mathrm{~N}$ mice imported from the NIH to the Central Institute for Experimental Animals (Kawasaki, Japan) at $\mathrm{F}_{121}$ in 1978 , and then transferred to CLEA Japan at $\mathrm{F}_{146}$ in 1988. C57BL/6NTac was introduced to Taconic Farms in 1991 from the NIH Animal Genetic Resource at $\mathrm{F}_{151}$. In this study we found a complete match in the genotypes of all SNP loci among these C57BL/6N substrains, in spite of their different histories, even after 20 to 30 years of separation. This result indicates that the genome of the C57BL/6N inbred strain has been maintained with high stability during extensive inbreeding for at least 30 years. It must be pointed out that further high-density SNPs analyses, such as with over 800 million SNPs [10], may reveal genetic differences among the C57BL/6N substrains in the near future.

The present study also clarified valuable information with regard to the genetic status of $\mathrm{C} 57 \mathrm{BL} / 6 \mathrm{CrSlc}$. According to Japan SLC, the mice were introduced as C57BL/6Cr to the Institute of Medical Science, The University of Tokyo in 1972 by Mr. Samuel M. Poiley (National Cancer Institute of the NIH, Bethesda), and then the mice were transferred to Japan SLC in 1975. In this study, the SNP pattern of C57BL/6CrSlc mice was found to be the same as other $\mathrm{C} 57 \mathrm{BL} / 6 \mathrm{~N}$ substrains. Incidentally, the $\mathrm{C} 57 \mathrm{BL} / 6 \mathrm{NCr}$ strain is currently available from the National Cancer Institute of the NIH, 
Frederick (NCI-Frederick). C57BL/6NCr was introduced to NCI-Frederick from the NIH at $\mathrm{F}_{122}$ in 1977 at a later date than $\mathrm{C} 57 \mathrm{BL} / 6 \mathrm{Cr}$ to Japan from the NCI, indicating that the origin of $\mathrm{C} 57 \mathrm{BL} / 6 \mathrm{CrSlc}$ is different from that of $\mathrm{C} 57 \mathrm{BL} / 6 \mathrm{NCr}$.

Our data clearly indicate genetic differences among C57BL/6 substrains, especially $\mathrm{J}$ vs $\mathrm{N}$ with respect to SNPs. Our results may also indicate that there are more SNP differences between $\mathrm{J}$ and $\mathrm{N}$. Therefore, researchers must pay attention to the sequence data of their own C57BL/6 mice and compare them with the BLAST data created from the $\mathrm{C} 57 \mathrm{BL} / 6 \mathrm{~J}$ genome. It has been reported that there are phenotypic differences among C57BL/6 substrains (see introduction). All C57BL/6J substrains in this study showed the deletion of the Nnt gene, indicating that they must exhibit impaired glucose tolerance, as was found in the $\mathrm{C} 57 \mathrm{BL} / 6 \mathrm{~J}$ substrain [11, 15]. However, there has been an insufficient recognition among biomedical researchers of the existence of different C57BL/6 substrains. According to information provided by the developers of 659 congenic, semicongenic, spontaneous and induced mutant strains with the C57BL/6 background deposited at the RIKEN BioResource Center, there were mixed backgrounds among the C57BL/6 substrains (2\%) or uncertain C57BL/6 substrains (14\%). This kind of mix-up among substrains must be avoided for correct interpretation of the data of functional analyses of the genes. The SNP differences between $\mathrm{C} 57 \mathrm{BL} / 6 \mathrm{~J}$ and $\mathrm{N}$ demonstrated in this study should be useful for distinguishing the genetic background of genetically engineered strains.

Currently, three major large-scale mutagenesis programs, namely the KOMP (KnockOut Mouse Project), NorCOMM (North American Conditional Mouse Mutagenesis Project), and EUCOMM (European Conditional Mouse Mutagenesis) are operating and working together to mutate all protein-encoding genes in the mouse, using gene trapping and targeting in ES cells [17]. These projects plan to use the $\mathrm{C} 57 \mathrm{BL} / 6$ strain as the genetic background for the induced mutations. In Europe, largescale production of targeted ES cell lines is now underway in C57BL/6N ES cells by the Wellcome Trust Sanger Institute (http://www.sanger.ac.uk/Teams/Team87). In the future, an extremely large number of C57BL/6 mice carrying targeted mutations will be distributed all over the world. Researchers must seriously consider the substrain status of C57BL/6 when using such resources for investigating novel functions of genes. Our data strongly support the increasing importance of high quality control of the genetic background of knockout mice.

\section{Acknowledgment(s)}

We are grateful to Dr. Kaoru Tsuda, Ms. Masami Ichikawa, Ms. Naomi Kobayashi, and other staff at the RIKEN BioResource Center for their devoted cooperation. We also thank Dr. Patricia E. Fritz, Charles River Laboratories and Mr. Takeshi Sube, Japan SLC, Inc. for kindly providing the information about the origin of C57BL/6NCr and C57BL/6CrSlc, respectively. RIKEN BioResource Center is participating in the National BioResource Project (NBRP) by the Ministry of Education, Culture, Sports, Science and Technology (MEXT) of Japan, and is designated a central core facility of the NBRP for mouse resources in Japan.

\section{References}

1. Altman, P.L. and Kats, D.D. 1979. Inbred and Genetically Defined Strains of Laboratory Animals, Part 1 Mouse and Rat (Altman, P.L. and Katz, D.D. eds.), Federation of American Societies for Experimental Biology, Bethesda, Maryland.

2. Bailey, D.W. 1978. Sources of subline divergence and their relative importance for sublines of six major inbred strains of mice. pp. 197-215. In: Origins of Inbred Mice (Morse III, H.C. ed.), Academic Press, New York.

3. Clapcote, S.J. and Roder, J.C. 2004. Survey of embryonic stem cell line source strains in the water maze reveals superior reversal learning of 129S6/SvEvTac mice. Behav. Brain Res. 152: 35-48.

4. Committee on Standardized Genetic Nomenclature for Mice. 1963. A revision of the standardized genetic nomenclature for mice. J. Hered. 54: 159-162.

5. Diwan, B.A. and Blackman, K.E. 1980. Differential susceptibility of 3 sublines of C57BL/6 mice to the induction of colorectal tumors by 1,2-dimethylhydrazine. Cancer Lett. 9: 111-115.

6. Eppig, J.T. 2007. Mouse strain and genetic nomenclature: an abbreviated guide. pp. 79-98. In: The Mouse in Biomedical Research. History, Wild Mice, and Genetics, 2nd ed., Volume 1 (Fox, J.G., Barthold, S.W., Davisson, M.T., Newcomer, C.E., Quimby, F.W., and Smith, A.L. eds.), Elsevier, Inc., London.

7. Fan, J.B., Chee, M.S., and Gunderson, K.L. 2006. Highly parallel genomic assays. Nat. Rev. Genet. 7: 632-644. 
8. Festing, M.F. 1979. Inbred Strains in Biomedical Research, The Macmillan Press Ltd., London and Basingstoke.

9. Festing, M.F. 1996. Origins and Characteristics of Inbred Strains of Mice. pp. 1537-1576. In: Genetic Variants and Strains of the Laboratory Mouse (Lyon, M.F., Rastan, S., and Brown, S.D.M. eds.), Oxford University Press, Oxford.

10. Frazer, K.A., Eskin, E., Kang, H.M., Bogue, M.A., Hinds, D.A., Beilharz, E.J., Gupta, R.V., Montgomery, J., Morenzoni, M.M., Nilsen, G.B., Pethiyagoda, C.L., Stuve, L.L., Johnson, F.M., Daly, M.J., Wade, C.M., and Cox, D.R. 2007. A sequence-based variation map of 8.27 million SNPs in inbred mouse strains. Nature 448: 1050-1053.

11. Freeman, H.C., Hugill, A., Dear, N.T., Ashcroft, F.M., and Cox, R.D. 2006. Deletion of nicotinamide nucleotide transhydrogenase: a new quantitive trait locus accounting for glucose intolerance in C57BL/6J mice. Diabetes 55: 2153-2156.

12. Green, M.L., Singh, A.V., Zhang, Y., Nemeth, K.A., Sulik, K.K., and Knudsen, T.B. 2007. Reprogramming of genetic networks during initiation of the Fetal Alcohol Syndrome. Dev. Dyn. 236: 613-631.

13. Grottick, A.J., Bagnol, D., Phillips, S., McDonald, J., Behan, D.P., Chalmers, D.T., and Hakak, Y. 2005. Neurotransmissionand cellular stress-related gene expression associated with prepulse inhibition in mice. Brain Res. Mol.Brain Res. 139: 153-162.

14. Grupe, A., Germer, S., Usuka, J., Aud, D., Belknap, J.K., Klein, R.F., Ahluwalia, M.K., Higuchi, R., and Peltz, G. 2001. In silico mapping of complex disease-related traits in mice. Science 292: 1915-1918.

15. Huang, T.T., Naeemuddin, M., Elchuri, S., Yamaguchi, M., Kozy, H.M., Carlson, E.J., and Epstein, C.J. 2006. Genetic modifiers of the phenotype of mice deficient in mitochondrial superoxide dismutase. Hum. Mol. Genet. 15: 1187-1194.

16. Hubbard, T.J., Aken, B.L., Beal, K., Ballester, B., Caccamo, M., Chen, Y., Clarke, L., Coates, G., Cunningham, F., Cutts, T., Down, T., Dyer, S.C., Fitzgerald, S., Fernandez-Banet, J., Graf, S., Haider, S., Hammond, M., Herrero, J., Holland, R., Howe, K., Howe, K., Johnson, N., Kahari, A., Keefe, D., Kokocinski, F., Kulesha, E., Lawson, D., Longden, I., Melsopp, C., Megy, K., Meidl, P., Ouverdin, B., Parker, A., Prlic, A., Rice, S., Rios, D., Schuster, M., Sealy, I., Severin, J., Slater, G., Smedley, D., Spudich, G., Trevanion, S., Vilella, A., Vogel, J., White, S., Wood, M., Cox, T., Curwen, V., Durbin, R., Fernandez-Suarez, X.M., Flicek, P., Kasprzyk, A., Proctor, G., Searle, S., Smith, J., Ureta-Vidal, A., and Birney, E. 2007. Ensembl 2007. Nucleic Acids Res. 35: D610-D617.

17. International Mouse Knockout Consortium, Colins, F.S., Rossant, J., and Wurst, W. 2007. A mouse for all reasons. Cell 128: 9-13.

18. Khisti, R.T., Wolstenholme, J., Shelton, K.L., and Miles, M.F. 2006. Characterization of the ethanol-deprivation effect in substrains of C57BL/6 mice. Alcohol 40: 119-126.

19. Mayorga, A.J. and Lucki, I. 2001. Limitations on the use of the C57BL/6 mouse in the tail suspension test. Psychopharmacology (Berl) 155: 110-112.
20. Mouse Genome Sequence Consortium, Waterston, R.H., Lindblad-Toh, K., Birney, E., Rogers, J., Abril, J.F., Agarwal, P., Agarwala, R., Ainscough, R., Alexandersson, M., An, P., Antonarakis, S.E., Attwood, J., Baertsch, R., Bailey, J., Barlow, K., Beck, S., Berry, E., Birren, B., Bloom, T., Bork, P., Botcherby, M., Bray, N., Brent, M.R., Brown, D.G., Brown, S.D., Bult, C., Burton, J., Butler, J., Campbell, R.D., Carninci, P., Cawley, S., Chiaromonte, F., Chinwalla, A.T., Church, D.M., Clamp, M., Clee, C., Collins, F.S., Cook, L.L., Copley, R.R., Coulson, A., Couronne, O., Cuff, J., Curwen, V., Cutts, T., Daly, M., David, R., Davies, J., Delehaunty, K.D., Deri, J., Dermitzakis, E.T., Dewey, C., Dickens, N.J., Diekhans, M., Dodge, S., Dubchak, I., Dunn, D.M., Eddy, S.R., Elnitski, L., Emes, R.D., Eswara, P., Eyras, E., Felsenfeld, A., Fewell, G.A., Flicek, P., Foley, K., Frankel, W.N., Fulton, L.A., Fulton, R.S., Furey, T.S., Gage, D., Gibbs, R.A., Glusman, G., Gnerre, S., Goldman, N., Goodstadt, L., Grafham, D., Graves, T.A., Green, E.D., Gregory, S., Guigó, R., Guyer, M., Hardison, R.C., Haussler, D., Hayashizaki, Y., Hillier, L.W., Hinrichs, A., Hlavina, W., Holzer, T., Hsu, F., Hua, A., Hubbard, T., Hunt, A., Jackson, I., Jaffe, D.B., Johnson, L.S., Jones, M., Jones, T.A., Joy, A., Kamal, M., Karlsson, E.K., Karolchik, D., Kasprzyk, A., Kawai, J., Keibler, E., Kells, C., Kent, W.J., Kirby, A., Kolbe, D.L., Korf, I., Kucherlapati, R.S., Kulbokas, E.J., Kulp, D., Landers, T., Leger, J.P., Leonard, S., Letunic, I., Levine, R., Li, J., Li, M., Lloyd, C., Lucas, S., Ma, B., Maglott, D.R., Mardis, E.R., Matthews, L., Mauceli, E., Mayer, J.H., McCarthy, M., McCombie, W.R., McLaren, S., McLay, K., McPherson, J.D., Meldrim, J., Meredith, B., Mesirov, J.P., Miller, W., Miner, T.L., Mongin, E., Montgomery, K.T., Morgan, M., Mott, R., Mullikin, J.C., Muzny, D.M., Nash, W.E., Nelson, J.O., Nhan, M.N., Nicol, R., Ning, Z., Nusbaum, C., O’Connor, M.J., Okazaki, Y., Oliver, K., Overton-Larty, E., Pachter, L., Parra, G., Pepin, K.H., Peterson, J., Pevzner, P., Plumb, R., Pohl, C.S., Poliakov, A., Ponce, T.C., Ponting, C.P., Potter, S., Quail, M., Reymond, A., Roe, B.A., Roskin, K.M., Rubin, E.M., Rust, A.G., Santos, R., Sapojnikov, V., Schultz, B., Schultz, J., Schwartz, M.S., Schwartz, S., Scott, C., Seaman, S., Searle, S., Sharpe, T., Sheridan, A., Shownkeen, R., Sims, S., Singer, J.B., Slater, G., Smit, A., Smith, D.R., Spencer, B., Stabenau, A., Stange-Thomann, N., Sugnet, C., Suyama, M., Tesler, G., Thompson, J., Torrents, D., Trevaskis, E., Tromp, J., Ucla, C., Ureta-Vidal, A., Vinson, J.P., Von Niederhausern, A.C., Wade, C.M., Wall, M., Weber, R.J., Weiss, R.B., Wendl, M.C., West, A.P., Wetterstrand, K., Wheeler, R., Whelan, S., Wierzbowski, J., Willey, D., Williams, S., Wilson, R.K., Winter, E., Worley, K.C., Wyman, D., Yang, S., Yang, S.P., Zdobnov, E.M., Zody, M.C., and Lander, E.S. 2002. Initial sequencing and comparative analysis of the mouse genome. Nature 420 : 520-562.

21. Petkov, P.M., Ding, Y., Cassell, M.A., Zhang, W., Wagner, G., Sargent, E.E., Asquith, S., Crew, V., Johnson, K.A., Robinson, P., Scott, V.E., and Wiles, M.V. 2004. An efficient SNP system for mouse genome scanning and elucidating strain relationships. Genome Res. 14: 1806-1811. 
22. Radulovic, J., Kammermeier, J., and Spiess, J. 1998. Generalization of fear responses in $\mathrm{C} 57 \mathrm{BL} / 6 \mathrm{~N}$ mice subjected to one-trial foreground contextual fear conditioning. Behav. Brain Res. 95: 179-189.

23. Roth, D.M., Swaney, J.S., Dalton, N.D., Gilpin, E.A., and Ross Jr., J. 2002. Impact of anesthesia on cardiac function during echocardiography in mice. Am. J. Physiol. Heart Circ. Physiol. 282: H2134-H2140.

24. Sherry, S.T., Ward, M.H., Kholodov, M., Baker, J., Phan, L., Smigielski, E.M., and Sirotkin, K. 2001. dbSNP: the NCBI database of genetic variation. Nucleic Acids Res. 29: 308-311.

25. Siegmund, A., Langnaese, K., and Wotjak, C.T. 2005. Differences in extinction of conditioned fear in C57BL/6 substrains are unrelated to expression of alpha-synuclein. Behav. Brain Res. 157: 291-298.

26. Silver, L.M. 1995. Laboratory Mice, Oxford University Press, New York.

27. Sluyter, F., Marican, C.C., and Crusio, W.E. 1999. Further phenotypical characterisation of two substrains of C57BL/6J inbred mice differing by a spontaneous single-gene mutation. Behav. Brain Res. 98: 39-43.

28. Stiedl, O., Radulovic, J., Lohmann, R., Birkenfeld, K., Palve, M., Kammermeier, J., Sananbenesi, F., and Spiess, J. 1999. Strain and substrain differences in context- and tonedependent fear conditioning of inbred mice. Behav. Brain Res. 104: 1-12.
29. Toye, A.A., Lippiat, J.D., Proks, P., Shimomura, K., Bentley, L., Hugill, A., Mijat, V., Goldsworthy, M., Moir, L., Haynes, A., Quarterman, J., Freeman, H.C., Ashcroft, F.M., and Cox, R.D. 2005. A genetic and physiological study of impaired glucose homeostasis control in C57BL/6J mice. Diabetologia 48: 675-686.

30. Tsang, S., Sun, Z., Luke, B., Stewart, C., Lum, N., Gregory, M., Wu, X., Subleski, M., Jenkins, N.A., Copeland, N.G., and Munroe, D.J. 2005. A comprehensive SNP-based genetic analysis of inbred mouse strains. Mamm. Genome 16: 476-480.

31. Wade, C.M., Kulbokas III, E.J., Kirby, A.W., Zody, M.C., Mullikin, J.C., Lander, E.S., Lindblad-Toh, E., and Daly, M.J.2002. The mosaic structure of variation in the laboratory mouse genome. Nature 420: 574-578

32. Wiltshire, T., Pletcher, M.T., Batalov, S., Barnes, S.W., Tarantino, L.M., Cooke, M.P., Wu, H., Smylie, K., Santrosyan, A., Copeland, N.G., Jenkins, N.A., Kalush, F., Mural, R.J., Glynne, R.J., Kay, S.A., Adams, M.D., and Fletcher, C.F. 2003. Genome-wide single-nucleotide polymorphism analysis defines haplotype patterns in mouse. Proc. Natl. Acad. Sci. 100: 3380-3385.

33. Zhang, J., Hunter, K.W., Gandolph, M., Rowe, W.L., Finney, R.P., Kelley, J.M., Edmonson, M., and Buetow, K.H. 2005. A high-resolution multistrain haplotype analysis of laboratory mouse genome reveals three distinctive genetic variation patterns. Genome Res. 15: 241-249. 